\title{
COMMUNITY SOCIAL WELFARE MODELING
}

Jolita GREBLIKAITE், Business and Rural Development Management, Faculty of Economics and Management,Institute Aleksandras Stulginskis University, Studentu st. 11, LT-53361 Akademija, Kauno r., Lithuania, jolita.greblikaite@asu.lt

MilitaVIENAŽINDIENĖ, Business and Rural Development Management, Faculty of Economics and Management,Institute Aleksandras Stulginskis University, Studentu st. 11, LT-53361 Akademija, Kauno r., Lithuania, milita.vienazindiene@asu.lt (corresponding author)

Regina ANDRIUKAITIENĖ, Faculty of Bussiness and Technology, Marijampole college, Kosmonautu st. 11, LT-68144, Marijampolè, Lithuania, regina.andriukaitiene@mkolegija.lt

\begin{abstract}
The social welfare of the community, as a reflection of the quality of life, is characterized by a dynamic and complex nature, and is now becoming an increasingly relevant and more debatable topic in the scientific community. An integrated assessment of social welfare becomes the most important prerequisite for increasing the quality of life. The theoretical studies of social welfare assessment have shown that in order to assess it, a systematic approach is needed that distinguishes living quality factors and their groups and identifies the relationships between them. It is obvious that only the assessment of the existing social welfare situation can form the direction of improving the quality of life.

In this article the authors, analyzing the issue of social welfare management as one of the most painful problems of the community today, define the concept of quality of life and social welfare, identify factors of social welfare quality and their assessment indicators, reveal the peculiarities of community-oriented activities. Based on the analysis of scientific literature, the authors of the article present a conceptual model illustrating community social welfare management and improving the quality of social life by responding to the needs of the community. The model consists of 5 main stages, each stage solving individual tasks. In the initial stages, an analysis of the current situation is carried out in the aspect of determinants of social welfare, the existing level is determined and comparison with the previous periods is performed. In the next stages a social welfare development plan is being prepared and implemented. According to the authors, applying the proposed model of social welfare management in the community, it is possible to ensure a higher level of social quality of life. Research method is the analysis and synthesis of scientific literature, logical, comparative and graphic representation.
\end{abstract}

Keywords: social welfare, social welfare indicators, community, management.

\section{INTRODUCTION}

Social welfare in life quality research is gaining more and more importance. Such factors as income, material property are changed by the factors of social welfare, raising the family, social life and leisure time into the first place. The desire of the consumer, industrial society to make as much money as possible reduced free time, disrupted the balance of work-rest, so the weight of leisure time, time spent with the family in the quality of life increased. According to Orlova (2014), the quality of life is a theoretical construct linking different levels of social welfare analysis. These are: a) the macro level (common social conditions and assumptions); b) community level (specific capabilities, service infrastructure and quality); c) individual level (actual use of social resources as well as subjective assessment of opportunities, satisfaction from the perspective of individual experience). The use of the concepts of quality of life, welfare, well-being, standard of living alternately poses certain problems in social sciences: for example, the concept of welfare which is derived from economic discipline and traditionally perceived as a synonym of material well-being, is often used in academic discourse as a general term of describing good life or as a synonym for both the welfare and the quality of life terms. As Krutuliene (2012) states, academic discourse does not explicitly agree on the monosemantic definition of the concept of quality of life; it is important for researchers in their work to purify the meaning of the term expressing good life and to clearly define it, then the confusion of concepts can be avoided. However, Atkočiūnienè et al. (2014), Kaliatkaité, Bulotaite (2014), Lu et al. (2013), Gruzhevsk, Šabanov (2015), Islam (2015), and others interpret the term for social welfare in a broader context than the allocation of material resources. Starkauskiene (2011) states that research on quality of life currently prevails in the fields of medicine, ecology, social welfare and economic sciences, and notes that social welfare research includes community wellbeing, partnership, social division into social groups (stratification), their structure and relationships. In this regard, there may be significant social capital research that includes the mechanisms of culture, social system interaction, psychosocial life of distribution, and reproduction in any medium, provided the original author and source are credited. 
individuals, and corresponds to the principles of the market - exchange in different areas of activities of individuals and organizations, uniting them in order to improve the quality of life in both moral and material senses (Vveinhardt et al., 2014). Despite the growing interest in the concept of social welfare, the problem of community welfare dynamics and its management is not fully researched, but very relevant in the context of modern change.There is a lack of community research in analyzing cross-sectoral collaboration, leadership, social welfare and creating a modern, highly-functional design under the current conditions. The idea of the active welfare subject has become irresistible to both policy makers and academics and has taken a lead role in the transformation of twenty-first century social security systems. The dominant model emphasises moralised individual responsibility for 'wrong choices' and mandates behavioural change to become active (Wright, 2016.).

The lack of community-based social welfare management means is one of the obstacles to objectively identifying and assessing the factors that respond to the social welfare of communities, so that an action plan and measures to increase social welfare can be proposed. The object of the research - the social welfare of the community and its management.

The aim of the research - having identified the factors determining the social welfare of the community, to develop a conceptual model of social welfare management in the community. Research methods. Analyzing the quality of life social welfare concept, the content, community social welfare determining factors and their assessment, constructing the community social welfare management model, general scientific research methods were used: systematic and comparative analysis of scientific literature, methods of induction, deduction, graphical modeling and generalization methods.

\section{Definition of Quality of Life and Social Welfare}

Over the past few decades, researchers have proposed a number of different approaches to the structure of quality of life (welfare) concept and its evaluation (Diener, Suh 1997). In terms of content, the system of social indicators relates to such categories as "social welfare", "quality of life". According to the modern concept of sustainable development, quality of life is the result of the interaction of social, economic and environmental factors. The concept of social welfare is directly connected with the idea of the sustainable development, they are interconnected processes unified by the principle of intercomplementarity (Ivankina et al. 2015, Fleurbaey, 2015). The modern concept of quality of life is perceived as a certain social construct which consists of distinct social dimensions. To assess the quality of life, we must first understand the meaning of this term, its treatment, and define what it is. The concept of quality of life has been formulated for many centuries, and is still not defined in the same way. In the works of Lithuanian scientists it is often identified with other words of a similar but not identical meaning: welfare, well-being, standard of living, happy life, life satisfaction.

After analyzing scientific literature, it can be argued that there is no classification of generally accepted social welfare factors or indicators and unanimous opinion about the determinants of social welfare and their interrelation. Scientific literature only mentions the assumptions that can be used to distinguish and systematize social welfare factors and to analyze the relationships between them. This problem arises because there is no consensus in the scientific community in defining the concept of social welfare. Some authors treat social welfare as a combination of personal relationships, family, friends, and social life factors, while other researchers, analyzing social welfare, give the priority to social support and health care, i.e. to the outside environment of the quality of life. Nevertheless, in the recent period there are being developed scientific discussions in this field with a view to more precisely defining the term. In the last period, the social welfare research aims to purify the essence of the term by distinguishing not only material, but also sociopsychological indicators defining welfare. Table 1 presents the definition of social welfare through the concept of the term by emphasizing the importance of both the allocation of resources, but also communication, the development of social networks and psychological well-being.

Table 1. The Concept of Social Welfare

\begin{tabular}{|l|l|}
\hline \multicolumn{1}{|c|}{ Authors } \\
$\begin{array}{l}\text { Lu et al. } \\
\text { (2013) }\end{array}$ & $\begin{array}{l}\text { Social welfare is inseparable from the role played by the welfare state and the cooperation of non-governmental } \\
\text { organizations with the private and public sectors, because the concept of social welfare includes services, } \\
\text { programs or their sets that are designed to allocate or redistribute resources among people according to their } \\
\text { needs and to improve the life of both the individuals and families or the whole society. }\end{array}$ \\
\hline $\begin{array}{l}\text { Kaliatkaitė, } \\
\text { Bulotaite } \\
(2014)\end{array}$ & $\begin{array}{l}\text { Social welfare is "one of the dimensions of the concept of human well-being formulated by WHO (World Health } \\
\text { Organization), alongside with the other two components - physical and psychological well-being." }\end{array}$ \\
\hline $\begin{array}{l}\text { Atkočiūnienė } \\
\text { et al. (2014) }\end{array}$ & $\begin{array}{l}\text { Social welfare aims to reveal, emphasize the level of "satisfaction of the physical, intellectual and social needs of } \\
\text { the human" }\end{array}$ \\
\hline $\begin{array}{l}\text { Islam, (2015) } \\
\text { Social welfare includes the objective and subjective aspect of the phenomenon, the development of social } \\
\text { networks, the development of people's abilities, the development of social relations and trust, the provision of } \\
\text { income, the empowerment of the community and the promotion of its activity. }\end{array}$ \\
\hline $\begin{array}{l}\text { Gruževskis, } \\
\text { Sabanovas } \\
\text { (2015) }\end{array}$ & $\begin{array}{l}\text { Social welfare "is like a conglomeration of various indicators". The subjective concept of this welfare is also singled } \\
\text { out. Objective well-being is based on the satisfaction of the needs of the individual "in relation to the objective world", } \\
\text { while the subjective includes mental well-being: the concept of happiness, the sense of satisfaction. }\end{array}$ \\
\hline $\begin{array}{l}\text { Ivankina, } \\
\text { Latygovskaya } \\
\text { (2015) }\end{array}$ & $\begin{array}{l}\text { Social welfare is a complex integral indicator of the social sphere efficiency which reflects social health, welfare } \\
\text { standard, quality of living, and social security of the society system. In this connection, social welfare is the most } \\
\text { important indicator of stability comprising certain achievements and opportunities available in diverse vital } \\
\text { activities of the individual and society as a whole, i.e. policy, economics, legislation, and so on. }\end{array}$ \\
\hline
\end{tabular}




\section{Social Welfare Indicators and Peculiarities of Community-oriented Activity}

Social welfare criteria are formulated by the Independent Public Policy Institute established in London. Legatum annually performs welfare research in 142 countries with over $96 \%$ of the world's population and where more than $99 \%$ of the world GDP are created (Legatum Prosperity Index 2016). The Legatum Welfare Index is calculated on the basis of 89 criteria grouped into 8 categories - groups of the same significance criteria. Estimates are obtained by surveying at least 1200 residents in each of the countries covered by the study. The Institute defines welfare as the level of quality of material situation and living conditions according to social welfare index parameters: education; economics; entrepreneurship and opportunities; management; social security; personal freedom; social capital and health. Table 2 presents the determinants of life quality dynamics. It can be argued that legatum indicators of social welfare and the factors distinguished by the author are partly related.

Table 2. Factors Determining the Dynamics of the Quality of Life according to Šabanovas (2015)

\begin{tabular}{|l|l|l|}
\hline & \multicolumn{1}{|c|}{ Groups of factors } & \multicolumn{1}{c|}{ Factors } \\
\hline 1. & Social structure & $\begin{array}{l}\text { Education; Average age; Number of employees; The relationship between employed and } \\
\text { unemployed people }\end{array}$ \\
\hline 2. & Productive force & Population number; Number of working age population \\
\hline 3. & Infrastructure & $\begin{array}{l}\text { Road network; Railway network; Airports; Seaports; River ports; } \\
\text { European corridors }\end{array}$ \\
\hline 4. & Entrepreneurship & Number of enterprises; Corporate structure; Trends in the number of enterprises \\
\hline 5. & Global communication & Global relationship; Internet accessibility \\
\hline 6. & $\begin{array}{l}\text { Political structure } \\
\text { democracy) }\end{array}$ & $\begin{array}{l}\text { Representation of political parties in the authorities; Ability to express your opinion freely; } \\
\text { Number of the media; Authority level of magnitude towards the human }\end{array}$ \\
\hline 7. & Urbanization & Urbanization level; Number of rural population; Number of urban inhabitants \\
\hline 8. & $\begin{array}{l}\text { Territory hierarchical } \\
\text { system }\end{array}$ & Hierarchical division; Geographical location of the territories \\
\hline
\end{tabular}

The community-oriented development in Lithuania is analyzed by Kvieskiene G. (2003, 2005, 2008, 2015), Leliugienè I. (2011), Kvieskienė G., Kvieska V. (2012), Nefas S. (2013), Kvieskienė G., Celešienė E. (2014), Rutkauskas V. (2014), Bardauskiene D. (2014), Vorevičienè(2016) and others. The European Commission presented the new integration tools that can be used to implement territorial strategies, and there are indicated partnership contracts, operational programs and territorial dimensions: the community-initiated local development is defined (article 28-30 of the proposed General Statute Regulations) and integrated territorial investments (article 99 of the proposed General Statute Regulations ). According to Androniceanu, A. (2017), the integrated social services system is a component of the social protection system through which the state, the local public authorities and the society assure the prevention, limitation and elimination of the temporary and permanent effects of the situations generated by the poverty and big vulnerability. The integration of the social services system assures many approaches such as: policy level integration, the integration of all the social service types for all the beneficiaries in a unique system, the correlation of the social services with the social offerings, family level integration, unifying the system work methodology and the multidisciplinary integration on group level. In Lithuania today, there are actually two types of communities that differ in their structure (Table 3).

Table 3.Types of Communities

\begin{tabular}{|l|l|}
\hline \multicolumn{1}{|c|}{\begin{tabular}{c|} 
Community type \\
big city centre
\end{tabular}} & $\begin{array}{l}\text { These are economic, industrial and cultural centers which include: } \\
\text { District communities. Community boundaries are clearly defined, social services are carried out differently } \\
\text { in different regions. } \\
\text { Neighbourhoods that care for social-household matters. }\end{array}$ \\
\hline $\begin{array}{l}\text { Community of a } \\
\text { regional centre }\end{array}$ & $\begin{array}{l}\text { Administrative centers with 10,000 to 20,000 inhabitants. The community is made up of smaller } \\
\text { communities: } \\
\text { The town community is the most prominent example of a closed community with a population of 1,000 to } \\
\text { 3,000. Social needs are met in the district or county center. } \\
\text { Rural community with up to 1,000 inhabitants, connected by the use of services of social institutions: } \\
\text { school, post office, cultural institutions, etc. The most important social needs are met in the communities of } \\
\text { the town and district center. }\end{array}$ \\
\hline
\end{tabular}

Regarding the existing rural and urban communities in Lithuania, it is important to distinguish the main features that determine their difference (Leliūgienè I., 2012). The village has a small population, limited job options, poorly developed public services, there is a problem of time spending. The rhythm of life here is relatively moderate, slow, there remains relationship with nature. In the rural community there are noticed specific social-psychological processes of socialization: characteristic openness, strange anonymity, open relationships, there are no significant social and cultural differences. The smaller the village, the closer the communication between the youth, children and adults.

Cities have a high concentration in a limited area, a variety of human activities, and social-professional differentiation. However, these characteristics may vary slightly. It depends on the size of the city, its geographical location and the occupancy nature of the population. In old small towns there are surviving elements of some rural people. In large cities the socialization conditions are slightly different. Socialization here takes place under urban living 
conditions: anonymity predominants, business, short-term, rather superficial relationships of personal communication. There is insignificant territorial unity, neighborhood relations, reduced economic family support. Cities have a variety of cultural stereotypes, value orientations and lifestyles. The social status of urban people is inconsistent and their social mobility has increased. Traditions less influence the people's behavior, poor social control, and increased significance of self-control of behavior.

Researching the problems of communality in the world and in Lithuania, developing the principles of communality, safe neighbourhood, discussing the issues of modeling communal forms, seeking the meaningfulness of community education in the activities of municipalities, great potential is given to the primary chain namely- active communities and multidisciplinary and multifunctional, multi-criteria principles. Successful communities and regions rely on the creation of an intelligent and innovative environment that includes public and private institutions. The result of all this is the creation of the characteristics necessary for the region's economic success.

The activities and goals of community-based organizations can be very diverse, i.e. community mobilization for common activities, development of their communal identity, solution of community economic, social, environmental and other problems, organization of cultural and sport events, organization of occupation of the children and youth, education of population, training organization, dissemination of information, etc. Despite the variety of goals, their main purpose is increasing the level of social quality /welfare of life (Kang, 2015).

Dominance of cultural activity is considered to be the typical stage of development of community movement. Such activity helps to mobilize people, reduce distrust, and create a community-based atmosphere. In the long run, the communities become mature for other activities, they start thinking about community-based entrepreneurship, the possibility to provide social services and take business initiatives. The purpose of the communal organizations and the specifics of the ongoing activities determine the necessity to cooperate with various organizations, in particular with local authorities, such as the municipality, the neighbourhood. The intensity of cooperation with the local authorities is not dependent on the size of the community or on the goals of the community. It is noticed that the success of a community organization depends on the fact how many local people are involved.

From the viewpoint of Ivankina et al. (2015), the welfare assurance is provided by the civil society interested in the achievement and regulation of the balance between the private and the public. A civil society represents the moral and political method of organizing people in a community that demonstrates a phenomenon of autophagy, when people utilize themselves as a means of their survival, free choice and activity based on common values. According to Vorevičiene (2016), ensuring the community welfare and the empowerment to act independently in this area is a process of synergic interaction between the individual, the community, the organization and the broader range of social and political figures (Laverack, 2006; Ojhaa, et al., 2016). Therefore it is important to continue promoting the activities of NGOs (Lima, et al., 2016), communality and unity in all sectors and at all levels of government (as it is currently being done). Attention is drawn to the fact that a well-provided, cooperative, inclusive society is the foundation of the state building, which holds citizenship, patriotism and democracy on it.

However, the process of activation of the population is not simple, and the involvement of the population in the activities of communities and public organizations depends on many objective and subjective factors. According to the study conducted by the Ministry of Social Security and Labor of the Republic of Lithuania, it is possible to distinguish certain groups of factors motivating the population to participate in communal or public activities (see Table 4).

Table 4. Factors Motivating the Participation of the Population in Community Activities

\begin{tabular}{|c|c|}
\hline Factors & Explanation \\
\hline Problems & $\begin{array}{l}\text { Individuals who want to assure or improve the security of their families, their property, tend to join } \\
\text { organized communities which can be seen as a greater guarantee for solving current problems. }\end{array}$ \\
\hline Community stability & $\begin{array}{l}\text { Greater community activity occurs in areas where the migration rate is relatively poor and the population } \\
\text { circle is relatively stable. It is interesting that the stability of the community functions as a stimulating } \\
\text { positive factor in involving new members, regardless of the length of their own life in a specific locality. } \\
\text { Moreover, the general stability of the livelihood can increase the community satisfaction and encourage } \\
\text { the involvement of both locals and newcomers. }\end{array}$ \\
\hline $\begin{array}{l}\text { Individual and } \\
\text { collective motives }\end{array}$ & $\begin{array}{l}\text { According to scientists, the participating people are mostly motivated by such non-material personal } \\
\text { stimuli as self-realization or valuable experience. From collective stimuli, the feeling of community (the } \\
\text { feeling of being part of a community) and common values function the strongest. However, it is not, as } \\
\text { the motivating stimulus, pursuit of common goals. }\end{array}$ \\
\hline $\begin{array}{l}\text { Role of communal } \\
\text { organizations }\end{array}$ & $\begin{array}{l}\text { If some people engage themselves in public activities lead by personal initiatives, this part appreciates } \\
\text { the factor of "being invited". In this case, the role of agent is best performed by existing social networks } \\
\text { that involve potential communal organization members. }\end{array}$ \\
\hline $\begin{array}{l}\text { Demographic, social } \\
\text { characteristics. }\end{array}$ & $\begin{array}{l}\text { Education in its broader meaning (acquired qualification, previous experience, etc.) is almost without } \\
\text { exception an important factor influencing participation in public activities. More than that, well-educated } \\
\text { people are not only more inclined to get involved into activities, but their participation is also } \\
\text { characterized by higher intensity and contribution if compared to those with lower education. It is } \\
\text { believed that more educated, higher income earners are more active in solving common issues, in the } \\
\text { activities of organizations established for the purpose of representing the population. Participation in } \\
\text { organizations that were created on the grounds of hobbies, nationality, religious beliefs, etc., is less } \\
\text { dependent on social demographic characteristics. However, the income is not the main factor } \\
\text { determining participation in public activities and the intensity of participation. }\end{array}$ \\
\hline
\end{tabular}


To sum up, it may be argued that the peculiarities of community-oriented activities are the need for public interests related to living in a neighborhood or town. People having common interests and needs, seek to implement them through the establishment of a community organization. The main purpose of community organizations is to unite people into common activities, for example, for the tidying of residential surroundings, for organizing various community holidays, and for conducting other similar activities. The participation of the population in public activities, community involvement in solving acute living environment, cultural, social issues, is also an important means strengthening the quality of public policy decisions. The main motives encouraging residents to join the community activities are individual - communication need, self-realization. Collective motives, such as the desire to contribute to the attainment of community goals, to use their potential knowledge for the community benefit. The dissatisfaction of the population with the existing public services, their lack, the desire to improve the living environment also encourages them to unite and solve the problems together.

\section{Conceptual Model of Social Welfare Management in the Local Community}

Having done systematic analysis of scientific literature, after evaluating and summarizing theoretical insights of scientific works by Lithuanian and foreign authors (Atkočiūnienè et al., 2014; Orlova, 2014; Gruževskis, Šabanovas, 2015; Kaliatkaitè, Bulotaitè, 2014; Starkauskienè, 2011; Lu et al., 2013; Leliūgienè, 2012; Krutuliene், 2012; The Legatum prosperity index, 2016 et al.), the authors of the article present the theoretical model of community welfare management (see Figure 1).

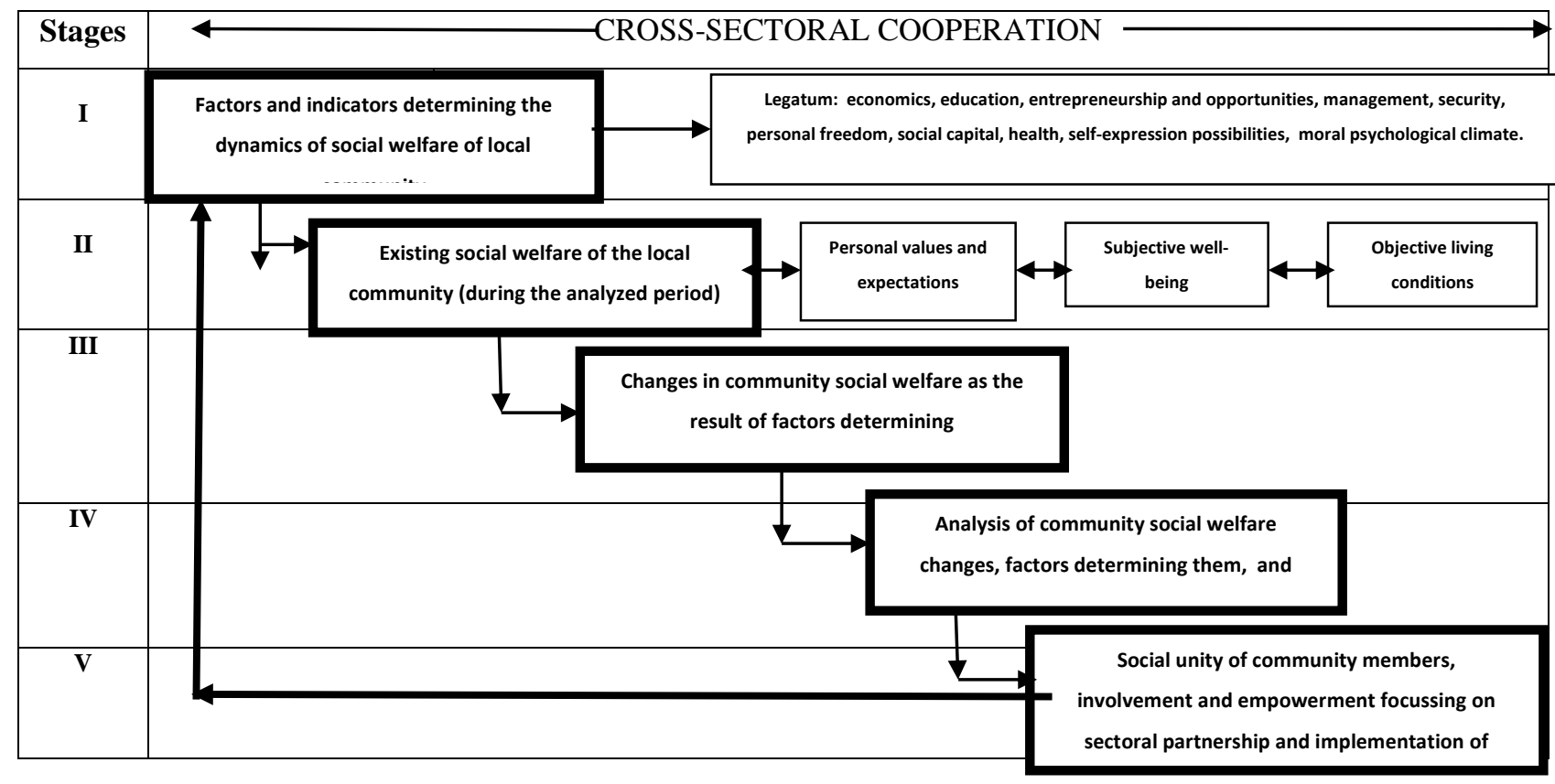

Figure 1 . The theoretical model of community welfare management in the local community (adapted by Legatum Prosperity Index 2015; Gruževskis B., Orlov U. L., 2012, p.12, Šabanov S, 2015, Vorevičienè, J. 2016 )

The authors of the article distinguish five stagesin the model, each of which consists of solutions to individual tasks. The first stage analyzes the factors determining the dynamics of the social well-being of the region / locality community and indicators in the fields of economics, education, entrepreneurship and posibilities, management, security, personal liberty, social capital, health, self-expression possibilities and moral-psychological climate. The second stage identifies the existing social welfare level during the analyzed period. At this stage, a survey is conducted by interviewing members of the community. In the third stage, the social welfare indicators of the community are compared with the results of the previous period, determining the physical, material, social, emotional welfare, development and activityexpectations of the members of the community, and their satisfaction with welfare issues. The objective living conditions are evaluated and the changes in social welfare of the community are summarized as the result of the factors determining the welfare dynamics. At the fourth stage, based on the results of the carried out research and analysis, the planning of social welfare development of the community is made. Planning is done with the participation of all local community groups. The fifth stage involves the implementation of planned measures, bringing together and involving community members. The implementation of the planned measures strengthens the crosssectoral partnership. Providing feedback. An important condition for increasing social welfare level is community unity, involvement, and the openness of staff at the management level and the promotion and development of cross-sectoral partnerships. This means that the essential information about the current situation and the planned changes is accessible, communicated to various community groups, community representatives are involved into the activities. The indicators of social welfare dynamics are systematically analyzed and the activities are performed under the recommended stages in the model.

\section{CONCLUSIONS}

Analyzing the development of the concept of public welfare in the scientific literature, it is obvious that the modern approach to welfare evaluation is wider and involves a higher number of indicators, it is no longer based solely on the 


\section{Proceedings of the $8^{\text {th }}$ International Scientific Conference Rural Development 2017}

results of measuring income, the methodology of evaluation uses complex multisectoral, multifunctional and multicriteria indices, consisting of individual factors. The peculiarity of activity oriented to the community is the implementation of the needs of public interests related to living in a neighborhood or town. Population participation in public activities, community involvement in solving actual issues of living environment, cultural, social, safety issues is also an important tool strengthening public policy decisions quality. The main motives encouraging the residents to join community activities are individual (communication needs, self-realization) and collective motives, such as a desire to contribute to community goals, using your own knowledge for community benefit. The dissatisfaction of the population with the existing public services, their lack, the desire to improve the living environment also encourage them to unite and solve problems together. The management of local community welfare, performing the analysis of factors in all stages of the process and applying plans of changes development measures, can lead to community members social unity, involvement and empowerment at the level of sectoral partnership, and ensuring feedback to enhance community welfare level.

\section{REFERENCES}

1. Androniceanu, A. 2017. Improvingcitizens' satisfaction concerning the social welfare services at urban level. Theoretical and Empirical Researchesin Urban Management, Vol. 12, No. 4, pp. 67-82.

2. Atkočiūnienè, V., Aleksandravičius, A., Kiaušienė, I., Vaznonienè, G., Pakeltienė, R., Lukè, R. 2014. Kaimo socialinès infratruktūros vystymas siekiant užtikrinti teritorinę ir socialinę sanglaudą. Mokslo studija. Akademija: Aleksandro Stulginskio universitetas. [In Lithuanian]

3. Dumbliauskienè, M., Jarmalavičienè, S. 2012. Gyvenimo kokybès kompleksinio vertinimo metodologinès problemos. Geografijos metraštis 45. [In Lithuanian]

4. Fleurbaey, M. 2015. On Sustainability and Social Welfare. Journal of Environmental Economics and Management, Vol. 71, pp. 34-53. https://doi.org/10.1016/j.jeem.2015.02.005

5. Gruževskis, B., Šabanovas, S. 2015. Modernios socialinès raidos samprata. Filosofija. Sociologija, Vol. 26 (4), pp. 267-276. [In Lithuanian]

6. Islam, M. R. 2015. NGOs' Social Capital Development Initiatives for Social Welfare: Bangladesh Experience. Global Social Welfare, Vol. 2, pp. 167-176. https://doi.org/10.1007/s40609-015-0034-0

7. Ivankina, L., Latygovskaya, T. 2015. Modern Social Welfare in the Light of the Sustainability Model. Procedia - Social and Behavioral Sciences, Vol. 166, pp. 111-115. https://doi.org/10.1016/j.sbspro.2014.12.493

8. Juozulynas, A, Butikis, M., Venalis, A., Narkauskaite, L., Jurgelènas, A. 2011. ActaMedica Lituanica, Vol. 18. No. 2. pp. $79-85$.

9. Kaliatkaitè, J., Bulotaite, L. 2014. Gerovès samprata sveikatos moksluose ir psichologijoje: tyrimai, problemos ir galimybès. Visuomenès sveikata, Vol. 1 (64), pp. 9-24. [In Lithuanian]

10. Kang, J.H., 2015. Participation in the Community Social Control, the Neighborhood Watch Groups: Individual - and Neighborhood-Related Factors. Crime Delinq, Vol. 61(2), pp. 188-212. https://doi.org/10.1177/0011128711398024

11. Krutulienè, S. 2012. Gyvenimo kokybè: sąvokos apibrèžimas ir santykis su gero gyvenimo terminais. Kultūra ir visuomené, Socialiniu tyrimu žurnalas, Vol. 3 (2), pp.117-130. [In Lithuanian]

12. Kvieskienė, G., Kvieska, V. 2012. Socialinès partnerystès ịtaka inovacijoms. Monografija: Edukologija. Vilnius, 265 p. [In Lithuanian]

13. Kvieskienè, G. 2003. Socializacija ir vaiko gerove. Monografija: Vilniaus pedagoginis universitetas, 249 p. [In Lithuanian]

14. Kvieskienė, G., Bardauskiené, D. 2014. I bendruomenę orientuota tvari plètra. Socialinis ugdymas: mokslo darbai, No. 39 , pp.7-22. [In Lithuanian]

15. Kvieskienė, G., Kvieska, V. 2012. Socialinès ekonomikos inovacijų įtaka visuomenès gerovei. Socialinis ugdymas, No .21(32). Vilnius: Edukologija, pp. 5-16.

16. Kvieskienè, G., Celiešienė, E. 2014. The Development of Indicators for Sustainable Education: Methodological and Conceptual Approaches. 8 th International Scientific Conference "BusinessandManagement 2014" May 15-16, 2014, Vilnius, Lithuania. Available at: https://doi.org/10.3846/bm.2014.100

17. Laverack, G. 2006. Improving health outcomes through community empowerment: a review of the literature. Journal of Health, Population, and Nutrition, Vol. 24, pp. 113-120.

18. Leliūgienè, I. 2012. Socioedukacinis darbas bendruomenèje. Kaunas: Technologija. [In Lithuanian]

19. Lima, S.H., Endo, C. 2016. The Development of the Social Economy in the Welfare Mix: Political Dynamics Between the State and the Third Sector. The Social Science Journal, Vol. 53, pp. 486-494. https://doi.org/10.1016/j.soscij.2016.09.002

20. Lu, S., Lin, Y.-T., Vikse, J. H., Huang, C.-C. 2013. Effectiveness of Social Welfare Programmes on Poverty Reduction and Income Inequalityin China. Journal of Asian Public Policy, Vol. 6 (3), pp. 277-291. https://doi.org/10.1080/17516234.2013.850226

21. Nefas, S., Narkevičiūtè, A. 2013. High-quality housing policy: the functional local community in Vilnius and Kaunas. Ekonomika ir vadyba : aktualijos ir perspektyvos, No. 3 (31), pp. 58-67.

22. Ojhaa, R. H., Fordb, R., Keenanb, J.R., Racec, D., Vegab, D. C., Baralb, H., Sapkotab, P. 2016. Delocalizing Communities: Changing Forms of Community Engagement in Natural Resources Governance. World Development, Vol. 87, pp. 274-290. https://doi.org/10.1016/j.worlddev.2016.06.017

23. Orlova, U. L. 2014. Socialiai globojamy vyresnio amžiaus asmenu gyvenimo kokybès veiksniai. Daktaro disertacija, Vilniaus universitetas. [In Lithuanian]

24. Starkauskienè, V. 2011. Gyvenimo kokybès veiksniai ir jos kompleksinio vertinimo modelis. Daktaro disertacija, VDU. [In 
Lithuanian]

25. Rutkauskas, A.V., Ignotas, A. Stasytytè, V., Kvieskienė, G., Celiešienė, E., Mikulskienė, B., Pitrėnaitė-Žilènienė, B., Navickas, V., Ruškytè, D., Podvezko, V. 2014. İ̌̌valgi investavimo strategija puoselèjant universaluji plètros tvarumą: mokslo monografija. Lietuvos edukologijos universitetas. Vilnius: BMK, 362 p. [In Lithuanian]

26. The legatum prosperity index, 2016. Available at: http://www.prosperity.com/globe/lithuania.

27. Vorevičienè, J. 2016. Trečiasis sektorius ir socialinè gerovè: nevyriausybinių organizacijų vaidmuo gerovès valstybejje. Kultūra ir visuomenè. Socialiniu tyrimu žurnalas, Vol.7 (2), pp. 49-71. [In Lithuanian]

28. Vveinhardt, J., Andriukaitiene, R., Cunha, L. M. 2014. Social Capital as a Cause and Consequence of Corporate Social Responsibility. Transformations in Business and Economics, Vol. 13(2A (32A)), pp. 483-505.

29. Wright, Sh. 2016. Conceptualising the active welfare subject: welfare reform in discourse, policy and lived experience. Policy \& Politics, Vol. 44 (2), pp. 235-252. https://doi.org/10.1332/030557314X13904856745154 